\title{
EFFECT OF CYSTEINE SUPPLEMENTATION ON FREEZABILITY OF BALADIE GOAT SPERMATOZOA
}

\author{
Metwaly, A. M.*; E. M. El-Siefy ${ }^{\star \star}$; R. S. El-Halawany ${ }^{\star}$ and B. \\ E. EL-Behnsawy* \\ ${ }^{*}$ Anim. Prod. Dept. Fac. of Agric., Kafr El-Sheikh Univ. \\ Egypt. ${ }^{* *}$ Biotechnology Res. Dept. Anim. Prod. Res. Insti., Agric. Res., \\ Center, Egypt
}

\begin{abstract}
The aim of this study was to assay supplementation of cysteine into the traditional egg yolk extender for cryopreservation of buck spermatozoa. Semen ejaculates were collected from three fertile baladie bucks, aged 2.0 - 3 years using artificial vagina. Collected semen was divided into four aliquots; the first was diluted with Tris-egg yolk extender without any supplementation (control), while the others were diluted with Tris-egg yolk extender supplemented with cysteine at levels of $0.5,2.5$ and $5 \mathrm{mM}$. Semen diluted at a rate of $1: 4$ and placed into a refrigerator at $5^{\circ} \mathrm{C}$ for $4 \mathrm{~h}$ to equilibrate. At the end of equilibration period, extended semen was packaged in $0.25 \mathrm{ml}$ French straws and stored at $-196^{\circ} \mathrm{C}$. Thereafter, frozen semen was thawed by dipping the straws into a water bath at $37^{\circ} \mathrm{C}$ for 30 seconds. Percentages of progressive motility, live sperm, sperm abnormalities, plasma membrane and acrosome integrity were evaluated post dilution, equilibration period and postthawing of goat semen.

The results revealed that there were a significant differences $(P<0.05)$ of the percentages of sperm motility, live spermatozoa, sperm abnormalities and plasma membrane and acrosome integrity among post-dilution, post equilibration and post thawing of buck semen. Treatment supplemented with $2.5 \mathrm{mM}$ of cysteine led to significantly $(P<0.05)$ improve the percentages of progressive motility, live spermatozoa, sperm abnormalities and plasma membrane and acrosome integrity of buck spermatozoa during different stages of cryopreservation compared to control and other levels of cysteine addition. In conclusion, supplementation of based Tris-egg yolk extender with $2.5 \mathrm{mM}$ of cysteine improves the percentages of progressive motility, live spermatozoa, sperm abnormalities and plasma membrane and acrosome integrity of frozen-thawed buck spermatozoa.
\end{abstract}

Key words: buck spermatozoa, cysteine, freezing, semen quality

\section{INTRODUCTION}

Egg yolk is a major constituent of extenders used for storage and cryopreservation of semen of domestic animals including bull, ram, goat and pig. The main advantage of egg yolk extender is the fraction of low density lipoprotein which protects the sperm during cryopreservation (Amirat et al., 2005). However, wide variations in the 
constituents of egg yolk make the beneficial effect difficult to assess (Gil et al., 2003; Amirat et al., 2005). The artificial insemination (Al) in goats is biotechnological method providing augmentation of the genetic merit in goat flocks, successful preservation of superior male sperm will give the chance for future recalling even in the absence of those males (Leboeuf et al., 2000).

The aim of storage of semen is to prolong the fertilizing capacity of spermatozoa by reducing or detaining their motility and metabolic reaction (Evans and Maxwell, 1987). The main changes that occurred during storage included reduction in motility and morphological integrity of spermatozoa. It has been well defined that sperm freezing process has detrimental effect on post-thawed sperm quality (Aitken et al., 1998; Salamon and Maxwell, 2000). Improvement of the extender is necessary because the main injury to sperm occurs during dilution and cooling (Tasseron et al., 1977). Numerous studies have been carried out to evaluate fundamental biological properties of egg yolk in extender (Watson, 1995; Martinez et al., 2006; EL-Sharawy, 2010; Noha Hussein, 2011). Several studies have been carried out to determine the effect of cysteine and glutathione on post-thawed sperm quality in different species (Coyan et al., 2011; Sharafi et al., 2015; Uysal and Bucak, 2007; Atessahin et al., 2008; Zhandi and Ghadimi, 2014). Cysteine and glutathione have an important effect to diminish ROS during freeze-thawing process (Uysal and Bucak 2007). Cysteine has cryoprotective effect on the functional integrity of acrosome and mitochondria improving post thawed sperm motility in many species, ram (Uysal and Bucak, 2007) goat semen (Bucak and Uysal, 2008), bull semen (Bilodeau, et al., 2001). Andreea et al., (2010) found that adding cysteine $(10 \mathrm{mM})$ and vitamin $E(1 \mathrm{mM})$ leading to the improve frozen buck semen. In opposite, Perumal et al., (2011) reported that addition of $5 \mathrm{mM}$ Cysteine and $5 \mathrm{mM}$ glutathione before freezing did not improve post-thaw progressive forward motility and total motility of the Jersey bull spermatozoa. The aim of this study was to evaluate the potential protective effect of cysteine on buck sperm characteristics including motility, livability, sperm abnormality, plasma membrane and acrosome integrity during different stages of cryopreservation.

\section{Experimental Animals}

\section{MATERIALS AND METHODS}

This study was carried out at the farm of Faculty of Agriculture, Kafr EL-Sheikh University. Three sexually mature bucks aged $2.0-3$ years old with an average body weight of 60 kilogram were used during the period from March 2015 to July 2016. All bucks were healthy and free of internal and external parasites. Palpation of the external genitalia 
showed that they were typically normal. The testicular tone was glandular, almost equal in size and moved freely up and down within the scrotal pouches. The animals were kept under natural photoperiod and balanced nutritional status. The rations offered to bucks adjusted to meet their maintenance requirements according to NRC (2007). Fresh water was available at all the day.

\section{Semen collection and evaluation}

Following sexual preparation, semen was collected twice weekly by an artificial vagina from three bucks. Immediately after semen collection, ejaculates were held in a water bath at $37^{\circ} \mathrm{C}$ until evaluated. Ejaculates having more than $75 \%$ mass motility were pooled in order to have sufficient semen for treatments and to eliminate the buck effect. On each collection day, good semen ejaculates were diluted with Tris-egg yolk extender, thereafter, the diluted semen was divided into four parts: the first part was used without any supplementation (control), while the others three parts were supplemented with $0.5,2.5$ and $5 \mathrm{mM}$ of Cysteine. The sperm progressive motility was determined according to Melrose and Laing (1970), live and abnormal spermatozoa were evaluated using eosin negrosin mixture prepared as described by Hancock (1951), plasma membrane integrity of spermatozoa was according to Jeyendran et al., (1984). Acrosome integrity were assessed using Geimsa stain according to Watson (1975) in postdiluted, post-equilibrated and post-thawed semen.

\section{Semen extender}

Tris-based extender (cryopreservation control extender) consisted of $3.07 \mathrm{~g}$ Tris (hydroxymethyl amino methane), $1.64 \mathrm{~g}$ citric acid, $1.26 \mathrm{~g}$ fructose, $15 \mathrm{ml}$ egg yolk, $5 \mathrm{ml}$ glycerol, $0.05 \mathrm{~g}$ streptomycin, $0.25 \mathrm{~g}$ linco-spectin and completed with bi-distilled water up to $100 \mathrm{ml}$. While, in other three extenders, cysteine was added to Tris-based control extender at concentrations of $0.5,2.5$ and $5 \mathrm{mM}$. The dilution rate was 1:4.

\section{Semen processing}

Good ejaculates were further processed for freezing using $0.25 \mathrm{ml}$ French straws containing about $100 \times 10^{6}$ motile sperm before freezing. The control Tris-egg yolk and Tris- cysteine extenders were kept warm in a water bath at $37^{\circ} \mathrm{C}$ for $10 \mathrm{~min}$. then they were placed into a refrigerator at $5^{\circ} \mathrm{C}$ for 4 hours for gradual cooling and semen equilibration.

At the end of equilibration period, the extended semen was packaged in $0.25 \mathrm{ml}$ French straws. Extended semen was kept in an ice water bath to keep its temperature at $5^{\circ} \mathrm{C}$. Straws were transferred into a processing canister and located horizontally in static nitrogen vapor 4 $\mathrm{cm}$ above the surface of liquid nitrogen for 10 minutes. The straws were then placed vertically in a metal canister and immersed 
completely in liquid nitrogen container for storage at $-196^{\circ} \mathrm{C}$. Freezing process was done as the method described by Salisbury et al., (1978). For thawing, straws were dipped into a water bath at $37^{\circ} \mathrm{C}$ for 30 seconds.

\section{Statistical analysis}

Data were statistically analyzed using a statistical software (SPSS, version 18.0). One-way analysis of variance was used to test the significance of extenders on the studied traits (Steel et al., 1997). Means of the significantly affected traits were separated by Duncan Multiple Range Test (Duncan, 1955).

\section{progressive motility}

\section{Results}

Results presented in Table (1) showed that semen supplemented with $2.5 \mathrm{mM}$ cysteine recorded the slight increase in the percentage of progressive motility of buck spermatozoa, compared to the control and $5 \mathrm{mM}$ extenders. While, semen supplemented with $0.5 \mathrm{mM}$ cysteine showed the lower value than the other treatments. During equilibrium period, addition of $2.5 \mathrm{mM}$ cysteine led to improve $(P<0.05)$ sperm progressive motility compared to the control, while addition of 0.5 and $5 \mathrm{mM}$ cysteine resulted lower percentage of sperm motility compared to control. The percentage of frozen-thawed buck progressive motility were significantly $(P<0.05)$ higher in extenders supplemented with 2.5 $\mathrm{mM}$ and $5 \mathrm{mM}$ cysteine compared to the control and $0.5 \mathrm{mM}$ cysteine extenders, being the best in semen supplemented with $2.5 \mathrm{mM}$ cysteine.

Table (1): Effect of supplementation of cysteine on the percentage of buck sperm progressive motility during different stages of cryopreservation

\begin{tabular}{|c|c|c|c|c|}
\hline \multirow{2}{*}{ Stages } & \multirow{2}{*}{ Control } & \multicolumn{3}{|c|}{ Cysteine concentrations $(\mathrm{Mm})$} \\
\cline { 3 - 5 } & 0.5 & 2.5 & 5 \\
\hline post - dilution & $70.5^{\mathrm{a}} \pm 1.42$ & $66.4^{\mathrm{b}} \pm 1.18$ & $72.3^{\mathrm{a}} \pm 1.03$ & $\begin{array}{c}68.6^{\mathrm{ab}} \pm \\
1.36\end{array}$ \\
\hline $\begin{array}{c}\text { post }- \\
\text { equilibration }\end{array}$ & $60.5^{\mathrm{b}} \pm 1.25$ & $57.7^{\mathrm{b}} \pm 1.40$ & $65.0^{\mathrm{a}} \pm 1.50$ & $58.6^{\mathrm{b}} \pm 1.52$ \\
\hline $\begin{array}{c}\text { post }- \\
\text { thawing }\end{array}$ & $29.9^{\mathrm{c}} \pm 0.91$ & $31.8^{\mathrm{c}} \pm 1.01$ & $41.4^{\mathrm{a}} \pm 1.18$ & $36.8^{\mathrm{b}} \pm 1.01$ \\
\hline
\end{tabular}

\section{a, $b$ and $c$ : the different superscripts in the same row are significant at level $5 \%$. Live sperm}

Post dilution, only the percentage of live spermatozoa was significantly $(\mathrm{P}<0.05)$ higher with $2.5 \mathrm{mM}$ cysteine extender compared to the control and the other cysteine extenders (Table 2). Post equilibrium period, the addition of different concentrations of cysteine led to increase the percentages of live spermatozoa compared to the control, being the best $(\mathrm{P}<0.05)$ in $2.5 \mathrm{mM}$ cysteine. Post freezing and thawing, 
live sperm percentages in different cysteine extenders were significantly $(\mathrm{P}<0.05)$ higher compared to the control extender, being the best in $2.5 \mathrm{mM}$ cysteine extender.

Table (2): Effect of addition of cysteine on the percentage of buck live sperm during different stages of cryopreservation

\begin{tabular}{|c|c|c|c|c|}
\hline \multirow{2}{*}{ Stages } & \multirow{2}{*}{ Control } & \multicolumn{3}{|c|}{ Cysteine concentrations (Mm) } \\
\cline { 3 - 5 } & 0.5 & 2.5 & 5 \\
\hline post - dilution & $76.0^{\mathrm{b}} \pm 1.40$ & $71.0^{\mathrm{c}} \pm 0.97$ & $80.6^{\mathrm{a}} \pm 0.79$ & $75.1^{\mathrm{b}} \pm 1.29$ \\
\hline $\begin{array}{c}\text { post }- \\
\text { equilibration }\end{array}$ & $60.2^{\mathrm{b}} \pm 0.80$ & $62.3^{\mathrm{b}} \pm 1.38$ & $75.5^{\mathrm{a}} \pm 1.74$ & $61.2^{\mathrm{b}} \pm 1.40$ \\
\hline $\begin{array}{c}\text { post - } \\
\text { thawing }\end{array}$ & $36.0^{\mathrm{d}} \pm 0.93$ & $39.6^{\mathrm{c}} \pm 1.25$ & $51.5^{\mathrm{a}} \pm 1.04$ & $42.3^{\mathrm{b}} \pm 0.47$ \\
\hline
\end{tabular}

$a, b, c$ and $d$ : the different superscripts in the same row are significant at level $5 \%$.

\section{Sperm abnormality:}

It is of interest to note that the addition of $2.5 \mathrm{mM}$ cysteine during different stages of cryopreservation (post dilution, post equilibrium period and post thawing) led to decrease the percentage of sperm abnormality compared to the control extender. While the addition of $0.5 \mathrm{mM}$ cysteine increased the percentage of sperm abnormalities compared to the other cysteine and control extenders (Table, 3 ).

Table (3): Effect of addition of cysteine on the percentage of buck sperm abnormality during different stages of cryopreservation

\begin{tabular}{|c|c|c|c|c|}
\hline \multirow{2}{*}{ Stages } & \multirow{2}{*}{ Control } & \multicolumn{3}{|c|}{ Cysteine concentrations $(\mathrm{Mm})$} \\
\cline { 3 - 5 } & $8.4^{\mathrm{b}} \pm 0.20$ & 0.5 & 2.5 & 5 \\
\hline post - dilution & $9.0^{\mathrm{a}} \pm 0.13$ & $8.1^{\mathrm{b}} \pm 0.21$ & $8.5^{\mathrm{ab}} \pm 0.21$ \\
\hline $\begin{array}{c}\text { post - } \\
\text { equilibration }\end{array}$ & $8.4^{\mathrm{b}} \pm 0.20$ & $9.0^{\mathrm{a}} \pm 0.13$ & $8.1^{\mathrm{b}} \pm 0.21$ & $8.5^{\mathrm{ab}} \pm 0.21$ \\
\hline $\begin{array}{c}\text { post - } \\
\text { thawing }\end{array}$ & $11.2^{\mathrm{ab}} \pm 0.30$ & $11.6^{\mathrm{a}} \pm 0.15$ & $10.0^{\mathrm{c}} \pm 0.19$ & $11.0^{\mathrm{b}} \pm 0.13$ \\
\hline
\end{tabular}

$a, b$ and c: the different superscripts in the same row are significant at level $5 \%$.

\section{Plasma membrane integrity}

Sperm plasma membrane integrity percentage was significantly $(\mathrm{P}<0.05)$ higher in extender containing $2.5 \mathrm{mM}$ cysteine when compared with control, $0.5 \mathrm{mM}$ and $5 \mathrm{mM}$ concentrations of cysteine at all stages of cryopreservation (Table,4). It was observed also, addition of $5 \mathrm{mM}$ cysteine significantly $(P<0.05)$ improved the post thawed plasma membrane integrity percentage as compared to the control and $0.5 \mathrm{mM}$ cysteine extenders. 
Table (4) : Effect of addition of cysteine on the percentage of buck plasma membrane integrity during different stages of cryopreservation

\begin{tabular}{|c|c|c|c|c|}
\hline \multirow{2}{*}{ Stages } & \multirow{2}{*}{ control } & \multicolumn{3}{|c|}{ Cysteine concentrations (Mm) } \\
\cline { 3 - 5 } & 0.5 & 2.5 & 5 \\
\hline post - dilution & $73.2^{\mathrm{b}} \pm 1.01$ & $75.3^{\mathrm{b}} \pm 1.85$ & $80.5^{\mathrm{a}} \pm 1.28$ & $72.5^{\mathrm{b}} \pm 1.53$ \\
\hline $\begin{array}{c}\text { post }- \\
\text { equilibration }\end{array}$ & $64.2^{\mathrm{c}} \pm .951$ & $68.6^{\mathrm{b}} \pm 2.03$ & $75.6^{\mathrm{a}} \pm 1.44$ & $62.1^{\mathrm{c}} \pm 1.49$ \\
\hline post - thawing & $37.8^{\mathrm{c}} \pm 1.30$ & $37.1^{\mathrm{c}} \pm 1.05$ & $53.6^{\mathrm{a}} \pm 1.18$ & $43.1^{\mathrm{b}} \pm 1.51$ \\
\hline
\end{tabular}

a, b and c: the different superscripts in the same row are significant at level $5 \%$.

\section{Acrosome integrity}

High $(\mathrm{P}<0.05)$ percentage of sperm acrosomal integrity was observed in $2.5 \mathrm{mM}$ cysteine extender at stages of equilibration and post freezing processes compared to the control and other levels of cysteine (Table, 4).

Table (5): Effect of addition of cysteine on the percentage of buck acrosome integrity during different stages of cryopreservation

\begin{tabular}{|c|c|c|c|c|}
\hline \multirow{2}{*}{ Stages } & \multirow{2}{*}{ control } & \multicolumn{3}{|c|}{ Cysteine concentrations $(\mathrm{Mm})$} \\
\cline { 3 - 5 } & $0^{\mathrm{ab}}$ & 0.5 & 2.5 & 5 \\
\hline post - dilution & $78.9^{\mathrm{b}} \pm 1.27$ & $77.3^{\mathrm{b}} \pm 1.76$ & $81.8^{\mathrm{a}} \pm 0.84$ & $77.0^{\mathrm{b}} \pm 1.25$ \\
\hline $\begin{array}{c}\text { post - } \\
\text { equilibration }\end{array}$ & $66.8^{\mathrm{b}} \pm 1.63$ & $70.2^{\mathrm{b}} \pm 1.16$ & $75.5^{\mathrm{a}} \pm 1.52$ & $67.0^{\mathrm{b}} \pm 1.40$ \\
\hline post - thawing & $42.7^{\mathrm{b}} \pm 0.91$ & $41.9^{\mathrm{b}} \pm 1.51$ & $54.1^{\mathrm{a}} \pm 0.58$ & $44.9^{\mathrm{b}} \pm 0.80$ \\
\hline
\end{tabular}

$a, b$ : the different superscripts in the same row are significant at level $5 \%$.

\section{Discussion}

Due to the high speed of the sperm, depending on the generation of energy by the mid-piece mitochondrial oxidative phosphorylation, a high concentration of free radicals are produced inside and outside the sperm cells (Martin et al., 2004; Guthrie and Welch 2006). The increase of the production of reactive oxygen species (ROS) might damage the sperm cell membrane resulting in lower sperm motility and survival after storage at low temperatures (Salamon and Maxwell, 1995) which leads to diminishing the sperm penetration of the cervical mucus in vitro (Gillan et al., 1997).

Addition of either enzymatic or nonenzymatic specific antioxidants would impact a beneficial reduction to the free radicals. Natural compounds containing thiol group are considered precursors of intracellular reduced glutathione biosynthesis. supplementation of cysteine to the semen extender prevents loss of sperm motility by inhibition of lipid peroxidation caused by ROS in frozen-thawed bull semen (Bilodeau et al., 2000). Supplementing the freezing media of goat and ram semen by cysteine enhanced post-thaw motility (Uysal 
and Bucak, 2007; Atessahin et al., 2008; Bucak and Uysal, 2008) and improved membrane integrity of boar sperm (Funahashi and Sano, 2005).

Using high levels of cysteine did not protect goat sperm membrane and sperm viability during freezing as reported by Kulaksiz and Daskin (2010). Moreover, Uysal and Bucak (2007) demonstrated that increasing doses of cysteine $(15 \mathrm{mM})$ decreased post-thaw sperm abnormality and increased acrosomal damage in rams. In the present study, addition of cysteine exhibited positive effect on frozen buck sperm parameters such as motility, live sperm, sperm abnormalities and sperm membrane integrity and acrosome integrity. Furthermore, $2.5 \mathrm{mM}$ cysteine extender gives better results in frozen buck semen when comparing with other cysteine concentrations and control extenders. These findings are in agreement with Funahashi and Sano (2005), who reported that addition of low concentration of $5 \mathrm{mM}$ cysteine improved the viability and membrane integrity of boar spermatozoa during liquid storage.

Similarly, Anghel and Zamfirescu (2010) reported improvement in sperm cytological characteristics of frozen goat semen when tris extender supplemented with $5 \mathrm{mM}$ concentration of cysteine. Also, Uysal and Bucak (2007) reported that the best post thawing sperm parameters at $10 \mathrm{mM}$ concentrations of cysteine in ram semen. In the meantime, Kledmanee et al., (2013) showed that the protective effect of cysteine on carp chilled sperm was attained by using levels up to $1 \mathrm{mM}$ cysteine. Also, Moustafa and Mona (2015) observed that the best sperm survival in the tested cysteine level was found at the lowest concentration $(1 \mathrm{mM})$ in ram semen. Above this level, there found a significant $(\mathrm{P}<0.01)$ decline in sperm characteristics accompanied with increase free radicals and decreased antioxidant enzyme activity. This observation was also confirmed on post-thaw quality of Sahiwal bull semen (Ansari et al., 2011).

\section{Conclusion}

In conclusion, the experimental present findings demonstrated that supplementation of semen diluent with $2.5 \mathrm{mM}$ cysteine improves semen characteristics (percentages of sperm motility, live sperm, sperm abnormalities, plasma membrane integrity, and acrosome integrity) when compare with control during cooling and freezingthawing processes.

\section{References}

Aitken, R. J.; Gordon, E.; Harkiss, D.; Twigg, J. P.; Milne, P.; Jennigs, Z. and Irvine, D. S. (1998). Relative impact of oxidative stress on the functional 
competence and genomic integrity of human spermatozoa. Biol. Reprod., 59:1037-1046.

Amirat, L.; Anton, M.; Tainturier, D.; Chatagnon, G. R.; Battut, I. and Courtens, J. L. (2005). Modifications of bull spermatozoa induced by three extenders: biociphos, low density lipoprotein and Triladyl, before, during and after freezing and thawing. Reprod., 129: 535-543.

Andreea, A.; Stela, Z.; Coprean, D.; Dorina, N.; Sogorescu, E. and Busuricu, F. (2010). The effects of antioxidants on the cytological parameters of cryopreserved buck semen. Romanian Biotech. Letters 15: $26-32$.

Anghel, A. and Zamfirescu, S. (2010). Role of antioxidant additives in the protection of the cryopreserved semen against free radicals. Romanian Biotech. Letters, 15: 33-41.

Ansari, M. S.; Rakha, B.; Ullah, N.; Andrabi, S.M.H.; Khalid, M.; and Akhter, S. (2011). Effect of L-cysteine in tris-citric egg yolk extender on post thaw quality of Nili-Ravi buffalo (Bubalus bubalis) bull spermatozoa. Pakistan J. of Zool., 43: 41-47.

Atessahin, A. Bucak, MN. Tuncer, PB. Kizil, M. (2008). Effects of anti-oxidant additives on microscopic and oxidative parameters of Angora goat semen following the freeze-thawing process. Small Rumin. Res., 77: 38-44.

Bilodeau, J. F.; Chatterjee, S.; Sirard, M. A. and Gagnon, C. (2000). Levels of antioxidant defenses are decreased in bovine spermatozoa after a cycle of freezing and thawing. Molecular Reproduction and Development, 55: 282-288.

Bilodeau, J. F.; Blanchette, S.; Gagnon, I. C. and Sirard, M. A. (2001). Thiols prevent $\mathrm{H} 2 \mathrm{O} 2-$ mediated loss of sperm motility in cryopreserved bull semen. Theriogenology, 56: 275-286.

Bucak, M. N. and Uysal, O. (2008). The role of antioxidants in freezing of Saanen goat semen. Indian Vet. J. 85: 148-150.

Çoyan, K.; Başpınar, N.; Bucak, M. N. and Akalın, P. P. (2011). Effects of cysteine and ergothioneine on post-thawed Merino ram sperm and biochemical parameters. Cryobiology. 63(1), 1-6.

Duncan, D.B. (1955). Multiple Range and Multiple F. Test Biometrics, 11: 142.

El-Sharawy, M. E. (2010). Use of low density lipoproteins and glutamine to improve frozen buffalo bull semen. PhD thesis, agriculture Science (Animal Production), Faculty of Agriculture, Kafr El-Sheikh University, Egypt.

Evans, G. and Maxwell WC. (1987). Salamons' artificial insemination of sheep and goats (No. Ed. 2). Star printer pty Itd. Fiser PS, Ainsworth L, Fairfull RW. 1982. Cryosurvival of ram spermatozoa in hypertonic and isotonic diluents. Canadian J. Anim. Sci., 62: 425-428.

Funahashi, H. and Sano, T. (2005) . Select antioxidants improve the function of extender boar semen stored at $10^{\circ} \mathrm{C}$, Theriogenology, 6:1605-1616 .

Gil, J.; M. Rodriguez-Irazoqui; M., Lundeheim, N., Söderquist, L. and H.Rodríguez-Martínez, (2003). Fertility of ram semen frozen in Bioexcell and used for cervical artificial insemination. Theriogenology. 59:1157- 1170. 
Gillan, L.; Evans, G. and Maxwell, W. M. C. (1997). Capacitation Status and Fertility of Fresh and Frozen-Thawed Ram Spermatozoa. Reprod., Fertil. and Develop., 9: 481-488.

Guthrie, H. D. and Welch, G. R. (2006). Determination of Intracellular Reactive Oxygen Species and High Mitochondrial Membrane Potential in Viable Boar Sperm Using Fluorescence Activated Flow Cytometry. J. of Anim. Sci., 84: 2089-2100.

Hancock, J. I. (1951). A staining technique for the study of temperature shock in semen. Nature, Lond., $167: 223$.

Jeyendran, R. S.; Van Der Ven, H. H.; Perez-Pelaez, M.; Crabo, B. G. and Zaneveled, L. J. D. (1984). Development of an assay to assess the functional integrity of the human sperm membrane and its relationship to other semen characteristics. J. Reprod. Fertil., 70: 219-228.

Kledmanee, K.; Taweedet, S.; Thaijongruk, P.; Chanapiwat, P.; and Kaeoket, K. (2013). Effect of L-Cysteine on chilled carp ( cyprinus carpio) semen qualities. Vet. Med. 43: 91-97.

Kulaksiz, R. and Daskin, A. (2010). In Vitro Evaluation of Saanen Buck Semen Frozen in Different Extenders Supplemented with Various Antioxidants. Ankara Üniversitesi Veteriner Fakültesi Dergisi, 57: 151156.

Leboeuf, B.; Restall, B. and Salamon, S. (2000). Production and storage of goat semen for artificial insemination. Anim. Reprod. Sci., 62: 113-41.

Martin, G.; Sabido, O.; Durand, P. and Levy, R. (2004). Cryopreservation induces an apoptosis-like mechanism in bull sperm. Bio. of Reprod., 71: 28-37.

Martinez, C. O.; Juarez-Mosqueda Mde, L.; Hernandez, J. and Valencia, J. (2006). Cryopreservation of bull spermatozoa alters the pronuclear theca. Theriogenology, 66: 1969-1975.

Melrose, D. R. and Laing, J. A. (1970). The characteristics of normal semen. Ed. By J. A. laing Bailliere tindall and cassel. London.

Moustafa, M. Z. and Mona, A. A. (2015). Effect of nonenzymatic antioxidants on sperm motility and survival relative to free radicals and antioxidant enzymes of chilled-stored ram semen. Open J. of Anim. Sci., 5: 50-58.

Noha Hussein, A. (2011). Effect of diluents and rate of dilution on semen quality of bulls and buffalo-bulls. Ph. D Thesis, Veterinary Medicine Science (Theriogenology), Faculty of Veterinary Medicine, Alexandria University, Egypt.

NRC (2007). Nutrient Requirements of Small Ruminants: Sheep, Goats, Cervids, and New World Camelids. National Research Council of the National Academies, National Academies Press, Washington, D.C., U.S.A.

Perumal, P.; Selvaraju, S.; Selvakumar, S.; Barik, A. K.; Mohanty, D. N.; Das, S.; Das, R. K. and Mishra, P. C. (2011). Effect of pre-freeze addition of Cysteine Hydrochloride and Reduced Glutathione in semen of crossbred Jersey Bulls on sperm parameters and conception rates. Reprod. Dom. Anim., 46: 636-641.

Salamon, S. and Maxwell, W. M. C. (1995). Frozen storage of ram semen I. Processing, freezing, thawing and fertility after cervical insemination. 
Anim. Reprod. Sci., 37:185-249.

Salamon, S. and Maxwell, W. M. C. (2000). Storage of ram semen. Anim. Reprod. Sci., 62: 77-111.

Salisbury, G. W.; Van Demark, N. L. and Lodge, J. R. (1978). Physiol. of Reprod. and Al of cattle. H. freeman and Comp. San Francisco. U.S.A.

Sharafi, M.; Zhandi, M. and Sharif, A. A. (2015). Supplementation of soybean lecithin-based semen extender by antioxidants: complementary flowcytometric study on post-thawed ram spermatozoa. Cell Tissue Bank, 16: 261-269.

Steel, R. G. D.; Torrie, J. H. and Dieky, D .A. (1997). Principles and procedures of statistics. 3rd Ed. McGraw Hill Book Co. Inc., New York.

Tasseron, F.; Amir, D. and Schindler, H. (1977). Acrosome damage of ram spermatozoa during dilution, cooling and freezing. J. Reprod. and Fertil., 51: 461-462.

Uysal, O. and Bucak, M. N. (2007). Effects of Oxidized Glutathione, Bovine Serum Albumin, Cysteine and Lycopene on the Quality of FrozenThawed Ram Semen. Acta Vet. Brno., 76: 383-390.

Watson, P. F. (1975). Use of a Giemsa stain to detect changes in acrosome of frozen ram spermatozoa. Vet. Re. 97: 12-15.

Watson, P. F. (1995). Recent developments and concepts in the cryopreservation of spermatozoa and the assessment of their postthawing function. Reprod. Fertil. Dev., 7: 871-910.

Zhandi, M. and Ghadimi, V. (2014). Effect of glutathione-supplemented INRA82 extender on miniature Caspian stallion sperm quality during storage at $5{ }^{\circ} \mathrm{C}$. J. Equine Vet. Sci., 34: 606-610.

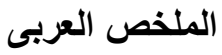

$$
\begin{aligned}
& \text { تأثير إضافة السيستين على حفظ الحيوانات المنوية لذكور الماعزالبلدى بالتجميد }
\end{aligned}
$$

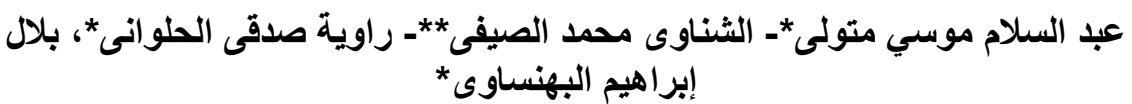

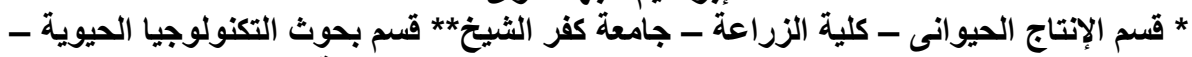

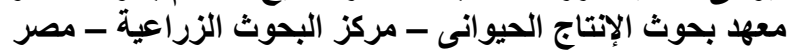




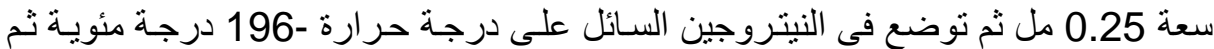

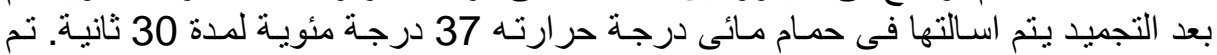

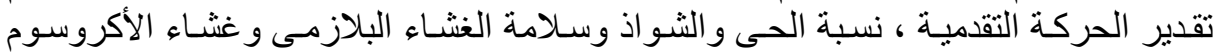

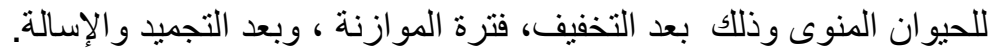

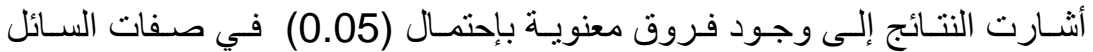

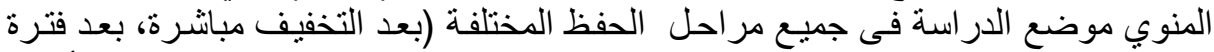

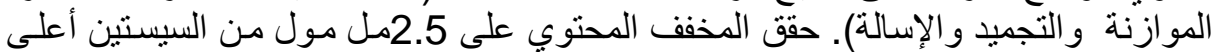

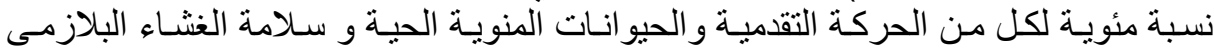

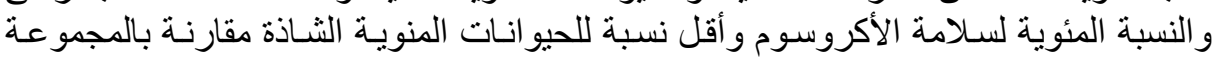

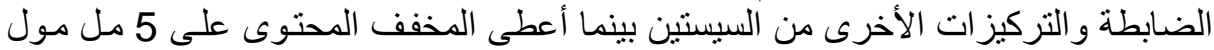

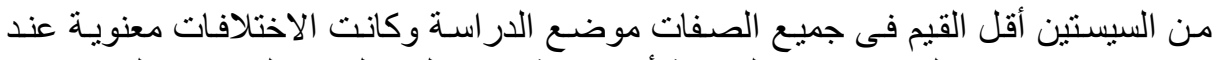

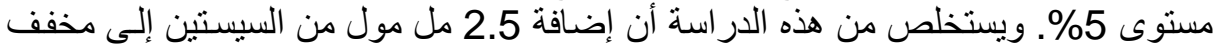

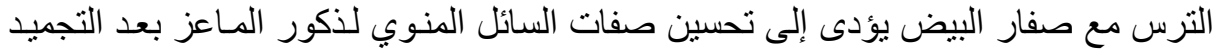
و الإسالة وبالتالى التنبؤ بزيادة نسب الإدى الإخصاب. 